\title{
A comparison of work stressors in higher and lower resourced emergency medicine health settings
}

Sebastian de Haan, MBChB*; Hein Lamprecht, MBChB*; Michael K. Howlett, MD, MHSA ; Jacqueline Fraser, $\mathrm{BN}^{\dagger}$; Dylan Sohi, $\mathrm{BSc}^{\ddagger}$; Anil Adisesh, MBChB, MSc, MD ; Paul R. Atkinson, $\mathrm{MB}, \mathrm{BCh}, \mathrm{BAO}, \mathrm{MA}^{+\boldsymbol{\top}}$

\author{
CLINICIAN'S CAPSULE \\ What is known about the topic? \\ Emergency physicians and trainees have high rates of \\ stress and burnout. \\ What did this study ask? \\ How do reported stressors for emergency physicians and \\ trainees differ between high and low resource settings? \\ What did this study find? \\ Trainees in the low resource setting reported higher \\ stressors. Trainees reported higher levels of stressors \\ than specialists in general. \\ Why does this study matter to clinicians? \\ High levels of reported stressors among trainees, and in \\ low resource settings should be acknowledged and \\ mitigated where possible.
}

\section{ABSTRACT}

Objectives: The study compares experiences of workplace stressors for emergency medicine trainees and specialists in settings where the specialty is relatively well resourced and established (Canada), and where it is newer and less well resourced (South Africa, (SA)).

Methods: We conducted an online cross-sectional survey of emergency medicine trainees and physicians in both countries for six domains (demands, role, support, change, control, and relationships) using the validated Management Standards Indicator Tool (MSIT, Health, and Safety Executive, United Kingdom).

Results: 74 SA and 430 Canadian respondents were included in our analysis. SA trainees $(n=38)$ reported higher stressors (lower MSIT scores) than SA specialists $(n=36)$ for demands (2.2 (95\% Cl 2.1-2.3) vs. $2.7(2.5-2.8))$, control (2.6 (2.4-2.7) vs. 3.5 (3.3-3.7)) and change (2.4 (2.2-2.6) vs. 3.0 (2.7-3.3)). In Canada, specialists $(n=395)$ had higher demands $(2.6(2.6-2.7)$ vs. 3.0 (2.8-3.1)) and manager support stressors (3.3 (3.3-3.4) vs. 3.9
(3.6-4.1)) than trainees $(n=35)$. Canadian trainees reported higher role stressors $(4.0(95 \% \mathrm{Cl} 3.8-4.1)$ vs. $4.2(4.2-4.3))$ than Canadian specialists. SA trainees had higher stressors on all domains than Canadian trainees. There was one domain (control) where Canadian specialists scored significantly lower than SA specialists, whereas SA specialists had significantly lower scores on peer support, relationships and role.

Conclusions: Work related stressor domains were different for all four groups. Perceived stressors were higher in all measured domains among SA trainees compared with Canadian trainees. The differences between the SA and Canadian specialists may reflect the developing nature of the specialty in SA, although the Canadian specialists reported less control over their work than SA counterparts.

\section{RÉSUMÉ}

Objectif: L'étude visait à comparer des facteurs de stress liés au travail chez des spécialistes et des stagiaires en médecine d'urgence dans des milieux où la spécialité est relativement bien établie et dispose de beaucoup de ressources (Canada) ou, au contraire, dans des milieux où la spécialité est récente et dispose de peu de ressources (Afrique du Sud [Afr. du Sud]).

Méthode: L'étude consistait en une enquête transversale, menée en ligne, dans les deux pays, parmi des spécialistes et des stagiaires en médecine d'urgence, dans six domaines d'action (les exigences, les rôles, le soutien, les changements, l'emprise sur le travail et les relations), à l'aide de l'instrument validé de mesure Management Standards Indicator Tool (MSIT), conçu par l'Health and Safety Executive (HSE), au Royaume-Uni.

Résultats: Ont été retenues dans l'analyse les réponses de 74 participants sud-africains et de 430 participants canadiens. En Afr. du Sud, les stagiaires $(n=38)$ ont fait état d'un état de stress plus élevé (résultats plus faibles au MSIT) que les spécialistes $(n=36)$ en ce qui concerne les exigences $(2,2$ [IC à

From the *Division of Emergency Medicine, Faculty of Medicine and Health Sciences, Stellenbosch University, South Africa; tDepartment of Emergency Medicine, Dalhousie University, Saint John Regional Hospital, Saint John, NB; ¥Faculty of Medicine, Memorial University, St. John's, NL; §Occupational Medicine, Dalhousie University, Dalhousie Medicine New Brunswick, Saint John, NB; and ๆOffice of the Chief Medical Officer, WorkSafeNB, Saint John, NB

Correspondence to: Dr. Hein Lamprecht, Division of Emergency Medicine, Faculty of Medicine and Health Sciences, University of Stellenbosch, PO Box 241, Cape Town 8000, South Africa; Email: hl@sun.ac.za 
$95 \%: 2,1-2,3]$ contre [c.] 2,7 [2,5-2,8]), I'emprise sur le travail $(2,6[2,4-2,7]$ c. $3,5[3,3-3,7])$ et les changements $(2,4$ [2,2-2,6] c. $3,0[2,7-3,3])$. Au Canada, les spécialistes $(n=395)$ ont fait état d'un degré de stress plus élevé que les stagiaires $(n=35)$ en ce qui concerne les exigences $(2,6[2,6-2,7]$ c. $3,0[2,8-3,1])$ et le soutien des gestionnaires $(3,3[3,3-3,4]$ c. $3,9[3,6-4,1])$. Quant aux stagiaires canadiens, ils ont indiqué un degré de stress plus élevé que les spécialistes canadiens en ce qui concerne les rôles $(4,0$ [IC à $95 \%: 3,8-4,1]$ c. 4,2 [4,2-4,3]). Dans l'ensemble, les stagiaires en Afr. du Sud avaient un degré de stress plus élevé que les stagiaires au Canada en ce qui concerne tous les domaines d'action. II y a toutefois un domaine dans lequel les spécialistes canadiens ont enregistré des résultats significativement plus faibles que les spécialistes sud-africains, soit l'emprise sur le travail, tandis que les spécialistes sud-africains ont enregistré des résultats significativement plus faibles que les spécialistes canadiens en ce qui concerne le soutien des pairs, les relations et les rôles.

Conclusions: Les facteurs de stress liés au travail étaient perçus différemment dans les quatre groupes. Dans I'ensemble, les facteurs de stress perçus par les stagiaires sud-africains étaient plus élevés dans tous les domaines que ceux perçus par les stagiaires canadiens. Quant aux spécialistes sud-africains et canadiens, les différences peuvent être le reflet de l'évolution de la spécialité en Afr. du Sud, mais les spécialistes au Canada ont indiqué avoir moins d'emprise sur leur travail que les spécialistes sud-africains.

Keywords: emergency medicine, management, occupational health, workplace stressors

\section{INTRODUCTION}

Occupational stress is a serious problem worldwide. The 2012 Global Workforce Study reported that four out of ten respondents were directly influenced by excessive pressure (stress) in the workplace. ${ }^{1}$ Occupational stress accounted for $35 \%$ of all work-related illnesses in the United Kingdom (UK) during 2014 and 2015. ${ }^{2}$ In Canada, occupational stress has an estimated financial cost of at least CDN\$20 billion per year with one in four Canadian workers describing their work lives as highly stressful. ${ }^{3,4}$ Unfortunately, no direct comparative statistics are available for the South African setting. However, the World Health Organization (WHO) noted that in 2004, 50\% of South African health care workers reported verbal abuse in the workplace that could be interpreted as evidence of occupational stress. ${ }^{5}$

The WHO defines occupational stress as the response workers may demonstrate if presented with work demands and pressures that are not matched to their knowledge and abilities and challenges their ability to cope. ${ }^{6}$ Both the WHO and UK Health and Safety Executive (HSE) acknowledge that all workers experience pressure at work on a daily basis by needing to perform continuously at their best. However, if workers experience excessive workrelated pressure, without the opportunity to sufficiently recover, it may result in occupational stress. ${ }^{7,8}$

Emergency medicine (EM) is regarded as one of the most stressful specialties in medicine. ${ }^{9-14}$ Sustained high occupational stress levels can manifest in many negative outcomes including poor mental and physical health, decreased career longevity, and eventual burnout. ${ }^{6,9,12,13}$ Recent surveys of doctors working in frontline medical specialties such as EM reported the highest prevalence of burnout. ${ }^{13,14}$ In Cape Town, South Africa (SA), a recent study analyzed doctors working in frontline community hospitals and noted that the prevalence of burnout and depression were as high as $76 \%$ and $27 \%$, respectively. ${ }^{15}$

EM is a relatively young specialty with a paucity of qualified specialists worldwide. Low resource settings (severe mismatch between health care supply and demand), such as SA, are especially affected by an acute shortage of EM specialists. In 2014, SA had 92 EM specialists certified by the Health Professions Council of South Africa (HPCSA), serving a population of 54 million. ${ }^{16}$ In contrast, EM in Canada has been a recognized specialty since 1982 . In 2014, Canada had over 3000 EM physicians and EM physicians in training to serve a population of just over 35 million. ${ }^{17}$

The 1999 Romanow Commission estimated that one EM physician was needed per 5000-patient emergency department (ED) visits per annum. ${ }^{18}$ This estimation translates to a requirement of 1000 EM physicians for the province of Ontario alone that far outstrips the number of currently practising EM physicians available. ${ }^{18}$ There is an overall severe shortfall of practising EM physicians for both Canada and SA, with the latter being much worse off.

Both the Canadian and South African public health care systems are based on similar social insurance principles for health care delivery. They offer a good comparative model to assess the impact of health care work-related stressors. The inclusion of both countries in the study was based on convenience, being representative of a low- and high-resourced setting, as well as the authors' unique insights of both countries EM health systems. Disparities between the work stressors of both 
countries may be explained by the marked difference in EM physicians' supply and demand and how the two EM systems are managed. Similarities may be because of the inherent stressors within the organization of the EM specialty itself and the nature of the work.

To bolster the number of EM specialists required to fill the severe shortfall, it is imperative to optimize the already stressful work environment by mitigating the occupational stressors currently experienced, thereby reducing the risk for any negative mental or physical effects to reduce attrition from an already underresourced profession.

We aimed to test the hypothesis that well-resourced Canadian EM physicians experience lower levels of work stress than their relatively under-resourced South African counterparts.

\section{METHODS}

\section{Study design}

We completed a cross-sectional electronic survey of EM physicians and trainees in Canada and SA. The study was approved by both the Health Research Ethics Committee at Stellenbosch University, South Africa (Ref: S14/07/146) and the Research Ethics Board of the Horizon Health Network, Saint John, NB, Canada (Ref: 2014-2033).

\section{Study population and setting}

The Canadian study population included all EM physicians and trainees that were registered with the Canadian Association of Emergency Physicians (CAEP). For SA, EM specialists who were registered with the HPCSA and EM specialist trainees who were registered with university academic EM specialty training programs were included in the study population. The study population excluded EM specialists and trainees who were practising outside of either SA or Canada.

\section{Sampling}

Between October and December 2014, emails were sent to all potential participants (the complete study population for both countries) inviting them to participate anonymously in the online survey. The invitational email had a link to the online platform for the survey. Three reminder emails were sent at regular one-month intervals to improve response rates.

\begin{tabular}{|c|c|c|}
\hline Key stressors & Description & $\begin{array}{c}\text { Survey } \\
\text { questions }\end{array}$ \\
\hline Demands & $\begin{array}{l}\text { Exerted by workload, work } \\
\text { patterns, and the work } \\
\text { environment }\end{array}$ & $\begin{array}{c}3,6,9,12,16 \\
18,20,22\end{array}$ \\
\hline Role & $\begin{array}{l}\text { The worker's understanding of } \\
\text { the role within the organization } \\
\text { and whether assurances are } \\
\text { given that the worker has no } \\
\text { conflicting roles }\end{array}$ & $1,4,11,13,17$ \\
\hline Support & $\begin{array}{l}\text { Encouragement and resources } \\
\text { provided by the organization, } \\
\text { management, and colleagues } \\
\text { (peers) }\end{array}$ & $\begin{array}{l}7,8,23,24 \\
27,29,31 \\
33,35\end{array}$ \\
\hline Change & $\begin{array}{l}\text { Management of organizational } \\
\text { change and the } \\
\text { communication thereof }\end{array}$ & $26,28,32$ \\
\hline Control & $\begin{array}{l}\text { The control the worker } \\
\text { possesses to do the work }\end{array}$ & $\begin{array}{l}2,10,15,19 \\
25,30\end{array}$ \\
\hline Relationships & $\begin{array}{l}\text { Promotion of positive work } \\
\text { practices to avoid conflict and } \\
\text { to deal with unacceptable } \\
\text { behaviour }\end{array}$ & $5,14,21,34$ \\
\hline
\end{tabular}

\section{Survey tool}

The validated management standards indicator tool (MSIT) (available at: http://www.hse.gov.uk/stress/stan dards/pdfs/indicatortool.pdf ) was developed by the UK HSE as a validated a psychometrically sound measure of organizational performance against the HSE management standards and can provide a broad overview of occupational stressors within organizations. ${ }^{19-22}$

The UK HSE identified six key work stressors that, if not managed properly, are associated with poor health and well-being, lower productivity, and increased absences. The six domains are demands, role, support, change, control, and relationships (see Table 1). ${ }^{21}$

We assessed these six key risk factors among our study sample (survey respondents) by sending a 35-item Likert scale-based MSIT questionnaire to the study population in both countries. The MSIT survey answers were weighted from one (poor) to five (desirable) measuring subjectively how well the employer is performing in managing each of the six work-related stressors in relation to the management standards. ${ }^{22}$

The survey also included demographic questions to assess occupational stressors in different categories (Table 2). 


\begin{tabular}{|c|c|c|c|c|c|}
\hline & & \multicolumn{2}{|c|}{ South African } & \multicolumn{2}{|c|}{ Canadian } \\
\hline & & $\begin{array}{c}\text { Trainees } \\
n=38(\%)\end{array}$ & $\begin{array}{l}\text { Specialists } \\
n=36(\%)\end{array}$ & $\begin{array}{c}\text { Trainees } \\
n=35(\%)\end{array}$ & $\begin{array}{l}\text { Specialists } \\
n=395(\%)\end{array}$ \\
\hline Sex & Male & $24(63)$ & $23(64)$ & $15(43)$ & $264(67)$ \\
\hline \multirow[t]{7}{*}{ Age (years) } & $18-24$ & 0 & 0 & 0 & 0 \\
\hline & $25-34$ & $29(76)$ & $6(17)$ & $32(91)$ & $43(11)$ \\
\hline & $35-44$ & $9(24)$ & $24(67)$ & $3(9)$ & 149 (38) \\
\hline & $45-54$ & 0 & $5(14)$ & 0 & 121 (31) \\
\hline & $55-64$ & 0 & $1(2)$ & 0 & $67(17)$ \\
\hline & $65-74$ & 0 & 0 & 0 & $15(4)$ \\
\hline & $>75$ & 0 & 0 & 0 & 0 \\
\hline \multirow[t]{6}{*}{ Years in practice } & $<5$ & $25(66)$ & $4(11)$ & $33(94)$ & $54(13)$ \\
\hline & $5-10$ & $12(32)$ & $17(47)$ & 0 & $1(0.3)$ \\
\hline & $11-20$ & $1(2)$ & $12(34)$ & 1 (3) & $138(35)$ \\
\hline & $21-30$ & 0 & $3(8)$ & 1 (3) & $157(40)$ \\
\hline & $31-40$ & 0 & 0 & 0 & $43(11.1)$ \\
\hline & $>40$ & 0 & 0 & 0 & $2(0.6)$ \\
\hline
\end{tabular}

\section{Analysis}

Continuous data were analyzed with IBM SPSS (v. 22 Statistical Package for the Social Science) software. The means and corresponding $95 \%$ confidence intervals (CI) were calculated for each of the demographic subsets and work stressor categories. The significance of differences in mean MSIT scores was compared with the independent samples $t$-test.

\section{RESULTS}

We received complete responses from 74 South African (50\% response rate) and 430 Canadian (33\% response rate) participants. Recruitment is further described in Figure 1. The two reasons that were identified and led to exclusions were incomplete surveys and participants not meeting the inclusion criteria.

Groups were balanced for gender, other than in the Canadian trainees' group, in which females represented the highest proportion (Table 2). Age distribution was similar for both trainee groups. The age distribution was younger for South African specialists than their Canadian peers, with the majority having practised for less than a decade. Eighteen percent of South African trainees indicated that they were considering leaving the EM profession in the next five years that contrasts strongly with the Canadian trainees. The lower potential for specialist attrition compares well between the two groups after allowing for age-related retirement.

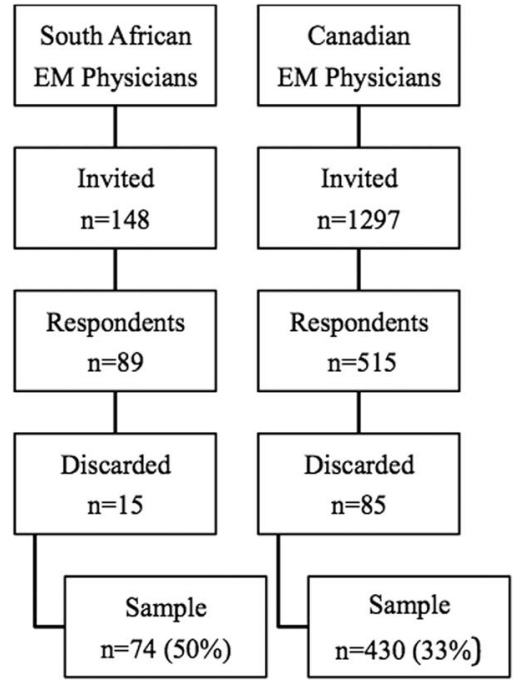

Figure 1. Recruitment flow diagram. $\mathrm{EM}=$ emergency medicine.

The survey results (see Table 3 and Figure 2) indicate that the South African EM trainees $(n=38)$ had the lowest scores (indicating highest stressors) on all measured stressor domains. Compared with Canadian trainee counterparts $(n=35)$, South Africans trainees had significantly worse reported stressor domain scores for demands (2.2 [95\% CI 2.1-2.3] v. $2.9[95 \%$ CI 2.8-3.1], respectively; $p<0.0001$ ); role $(3.6[95 \%$ CI 3.4-3.7] v. 4.0 [95\% CI 3.8-4.1], respectively; $p<0.0001)$; manager support (2.9 [95\% CI 2.7-3.1] v. 3.9 [95\% CI 3.6-4.1], respectively; $p<0.0001$ ); peer support $(3.3 \quad[95 \%$ CI $3.1-3.5]$ v. 4.0 [3.8-4.2], 
Work stressors among emergency medicine doctors

\begin{tabular}{|c|c|c|c|c|c|c|c|}
\hline & Demands & Role & Manager support & Peer support & Change & Control & Relationships \\
\hline \multicolumn{8}{|c|}{ South African EM trainees $(n=38)$} \\
\hline Mean & 2.22 & 3.56 & 2.88 & 3.29 & 2.38 & 2.56 & 3.30 \\
\hline $95 \% \mathrm{Cl}$ & $2.09-2.35$ & $3.38-3.74$ & $2.68-3.07$ & $3.10-3.49$ & $2.19-2.56$ & $2.38-2.75$ & $3.13-3.48$ \\
\hline \multicolumn{8}{|c|}{ South African EM specialists $(n=36)$} \\
\hline Mean & 2.66 & 4.02 & 3.23 & 3.57 & 3.00 & 3.51 & 3.40 \\
\hline $95 \% \mathrm{Cl}$ & $2.50-2.80$ & $3.73-4.30$ & $2.91-3.56$ & $3.28-3.86$ & $2.67-3.33$ & $3.30-3.72$ & $3.09-3.70$ \\
\hline \multicolumn{8}{|c|}{ Canadian EM trainees $(n=35)$} \\
\hline Mean & 2.95 & 3.99 & 3.86 & 4.03 & 3.17 & 3.21 & 3.86 \\
\hline $95 \% \mathrm{Cl}$ & $2.77-3.14$ & $3.85-4.14$ & $3.63-4.10$ & $3.85-4.22$ & $2.93-3.40$ & $2.98-3.45$ & $3.63-4.10$ \\
\hline \multicolumn{8}{|c|}{ Canadian EM specialists $(n=395)$} \\
\hline Mean & 2.61 & 4.22 & 3.34 & 3.86 & 3.04 & 3.26 & 3.73 \\
\hline $95 \% \mathrm{Cl}$ & $2.56-2.67$ & $4.17-4.27$ & $3.27-3.41$ & $3.81-3.92$ & $2.96-3.13$ & $3.19-3.33$ & $3.66-3.79$ \\
\hline
\end{tabular}

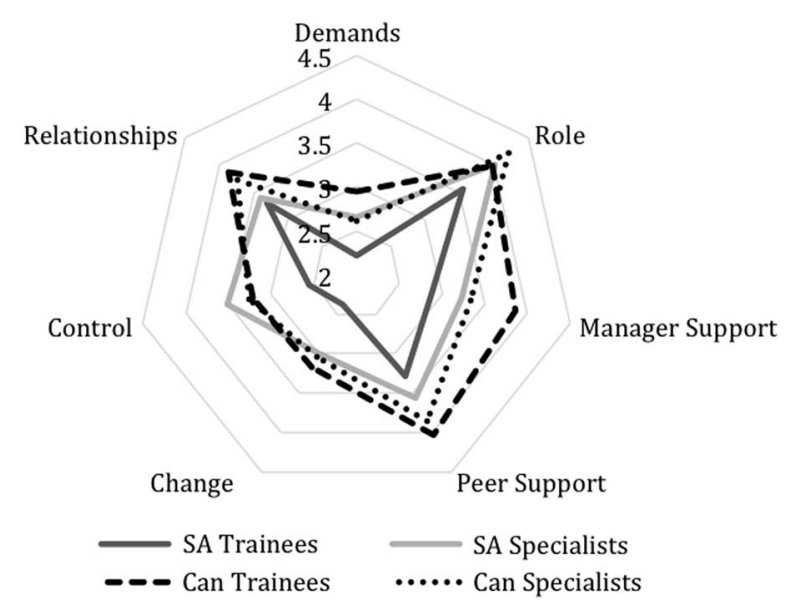

Figure 2. Key stressor comparisons among the four groups, by country and stage of career.

* Lower values (closer to the centre) represent higher stressor scores.

Can $=$ Canadian; $\mathrm{SA}=$ South African .

respectively; $p<0.0001)$; change (2.4 [95\% CI $2.2-2.6]$ v. $3.2[2.9-3.4]$, respectively; $p<0.0001) ;$ control (2.6 [95\% CI 2.4-2.7] v. 3.2 [3.0-3.4], respectively; $p<0.0001)$; and relationships (3.3 [95\% CI 3.1-3.5] v. 3.9 [3.6-4.1], respectively; $p<0.0001)$. Comparing South African and Canadian specialists, there was one domain (control) in which Canadian specialists scored significantly worse than South African specialists (3.26 [95\% CI [3.19-3.33] v. 3.51 [95\% CI [3.30-3.72], respectively; $p=0.038$ ), whereas South African specialists had significantly worse scores on peer support (357 [95\% CI 3.28-3.86] v. 3.86 [3.81-3.92], respectively; $p=0.004)$; relationships $(3.40[95 \% \mathrm{CI}$
3.09-3.70] v. 3.73 [95\% CI 3.66-3.79], respectively; $p=0.004) ;$ and role $(4.02 \quad[95 \%$ CI $3.73-4.30]$ v. 4.22 [95\% CI 4.17-4.27], respectively; $p=0.033$ ). South African trainees had significantly worse scores in work stressor levels for demands, change, control, and role domains, as compared with South African specialists. However, Canadian specialists had significantly worse scores related to experiencing work stressors from demands and manager support, as compared with Canadian trainees who had lower role domain scores (see Table 3).

\section{DISCUSSION}

\section{SA versus Canada}

South African EM trainees were found to adversely experience all six MSIT stressor categories (demands, role, support, change, control, and relationships), as compared with their Canadian counterparts. The low resource setting in SA may be a significant factor contributing to the high level of work stressors measured among their EM trainees. The high demands stressor may be caused by the limited access to medical equipment and disposables that prevents the provision of optimal patient care. Furthermore, chronic staff shortages, undermining optimal shift rotational planning and crossover cover, often result in higher duty hours than previously anticipated with fewer EM physicians available to share ever-increasing clinical workloads. Change management was the second lowest score (high stressor) for South African trainees, whereas the biggest difference 
in work stressor scores between the trainee groups was the managerial support reported by South African trainees. The South African trainees' low resource setting provides less flexibility in scheduling their work shifts that may have contributed to their higher work stressors. A 2009 study reported that patient care might be compromised by long physician hours, resulting in sleep deprivation, that, in turn, caused cognitive impairment, leading to an increased potential for medical errors to occur. ${ }^{23}$ Adverse conditions for residents have effects on their well-being and patient safety outcomes, although more recent studies have shown that flexibility in scheduling may still maintain learner health. ${ }^{24,25}$

The Canadian trainees' more favourable score for peer-support may be explained by strong representation, as well as a larger number of peers available for sharing the workload, resulting in more balanced clinical hours. Similar to the US, ${ }^{24,25}$ the hours of service by residents in Canada has been regulated closely by residency programs to reduce occupational stress and sleep deprivation. Canadian EM trainees are supported by collective agreements in their respective provincial jurisdictions to limit unhealthy working conditions, unlike their South African counterparts.

The differences between the South African and Canadian specialists may reflect the developing nature of the specialty in SA with peers being disparate and the role being less well defined and perhaps, partly as a consequence of relationships at work, being more pressured than for Canadian specialists. However, Canadian specialists reported more difficulty with control over their work that was perhaps not an anticipated finding.

The Canadian EM trainees scored similarly to a UK-based study by Basu et al. that also used MSIT. Both EM specialist groups performed less well except on the domains of change and control. However, the UK study used a much smaller group of EM physicians with more diverse experience levels. ${ }^{26}$

\section{EM trainees versus specialists}

The scores for South African EM trainees indicated higher stressors for demands, change, control, and role domains, in comparison with South African specialists. This may be explained by trainees working more and less sociable (shifts v. on call from home) clinical hours, as compared with specialists. Trainees have less management representation concerning daily operational decisions and future planning of the specialty itself that may have contributed to their higher control domain stressor results. Additionally, the specialty is still developing in SA, and the role of the trainee continues to evolve.

Canadian EM trainees had higher stressor scores for the role domain in comparison with Canadian EM specialists. This could potentially be attributed to trainees still exploring and defining their role within the EM specialty during their formative years.

Canadian specialists had less favourable stressor scores for demands and manager support, as compared with their trainees. The EM specialty is unique in that it requires specialists to be a clinical manager and liaison among patients, other specialties, and hospital management. This new managerial role is novel to most newly qualified EM specialists and requires substantive work experience and non-clinical management skills.

\section{LIMITATIONS}

The cross-sectional study design that was used could not provide work stressor severity and domain changes over time in relation to the EM physicians' career progression. The relatively low response rate $(33 \%)$ of the Canadian cohort may have skewed the results because of responder bias. Although the number of South African respondents was low $(n=89)$, their higher responder rate $(60 \%)$ was more representative of the study population. The impact of possible responder bias was limited by sending regular reminders to improve the responder rates in both surveys. Non-responder bias may also have influenced the study results. Specialists and trainees in both countries feeling aggrieved because of severe stress and were more likely to respond to the survey, resulting in an overestimation of the measured stressors. The South African responses were skewed toward Cape Town, as compared with the rest of the country, that was especially noted in the trainee group. This may be attributed to the primary investigator working in the Western Cape Province training group. However, Cape Town trains more than $60 \%$ of the national EM physicians.

Despite the internal limitations of the study, it was clear that work stressors were pervasive across both EM platforms irrespective of setting. The survey found that South African EM trainees were exposed to the highest levels of work stressors across all measured stressor indicators, as compared with South African specialists and their Canadian peers. However, the other three groups also demonstrated significant differences in their perception of work stressors, across different stressor indicators. 
This highlights some areas in which efforts could be focused to improve working and training conditions. Future qualitative research could help to explore underlying themes for the differences in the reporting of work stressor indicators among the respective four groups. This study has added further strength to the argument that a search for solutions to mitigate the effect of highly perceived work stressors is required. A Canadian study previously demonstrated that task-oriented coping (taking direct action to alter the situation itself) was associated with a decreased risk of burnout, while emotion-oriented coping (managing one's emotional responses to a situation) was associated with an increased risk of burnout. ${ }^{27}$ Our study provides useful data upon which stressor domains to focus management action while considering the challenges faced in EM.

The consequences of failing to act may contribute to mental health problems and possible attrition from the profession that would be concerning, given the existing shortage of EM physicians in both countries. The creation of an optimal work environment for all health care workers, in which work stressors are recognized as a potential threat and avoided or managed effectively, is needed.

\section{CONCLUSIONS}

Reported occupational stressors were found to be less favourable among EM trainees in SA. The more favourably reported occupational stressors among Canadian EM specialists and trainees may be explained by its higher resourced setting (facilities, equipment, consumables, and staff), as compared with SA, and perhaps by the fact that the specialty is more established in Canada and, therefore, has better regulation of the work environment for physicians.

Competing interests: None declared.

\section{REFERENCES}

1. Watson T. Global Workforce Study; 2012. Available at: https://www.towerswatson.com/en/Insights/IC-Types/SurveyResearch-Results/2012/07/2012-Towers-Watson-GlobalWorkforce-Study? webSyncID =83ba8e 57-d5a6-039c-4184d4d331e313e5\&sessionGUID=2849ec94-69c7-69b5-80a92589545 dd405 (accessed 8 September 2017).

2. Health and Safety Executive. Work related stress, anxiety and depression statistics in Great Britain 2014/15; 2015. Available at: http://www.hse.gov.uk/statistics/causdis/stress (accessed 8 September 2017).
3. Anderssen E. Ottawa to fund mental health strategy: First ever Canadian-wide standards to tackle problem estimated to cost \$20-billion a year in work place losses alone. The Globe and Mail 2011 Jun;A3.

4. Crompton S. What's stressing the stressed? Main sources of stress among workers. Statistics Canada. 2011. Available at: http://www.statcan.gc.ca/pub/11-008-x/2011002/article/ 11562-eng.pdf (accessed 8 September 2017).

5. WHO Media Centre. Available at: http://www.who.int/ mediacentre/news/releases/release37/en (accessed 8 September 2017).

6. Leka S, Griffiths A, Cox T. Work Organisation and Stress. World Health Organization; 2003. Available at: http://www. who.int/iris/handle/10665/42625 (accessed 8 September 2017).

7. Stress at the workplace. World Health Organization. Available at: http://www.who.int/occupational_health/topics/ stressatwp/en (accessed 8 September 2017).

8. Working together to reduce stress at work. Available at: http://www.hse.gov.uk/pubns/indg424.pdf (accessed 8 September 2017).

9. Gallery ME, Whitley TW, Klonis LK, Anzinger RK, Revicki DA. A study of occupational stress and depression among emergency physicians. Ann Emerg Med 1992;21(1): $58-64$.

10. Whitley TW, Allison EJ Jr, Gallery ME, et al. Work-related stress and depression among practicing emergency physicians: an international study. Ann Emerg Med 1994;23(5): 1068-71.

11. Whitley TW, Gallery ME, Allison EJ Jr, Revicki DA. Factors associated with stress among emergency medicine residents. Ann Emerg Med 1989;18(11):1157-61.

12. Burbeck R, Coomber S, Robinson SM, Todd C. Occupational stress in consultants in accident and emergency medicine: a national survey of levels of stress at work. Emerg Med 7 2002;19(3):234-8.

13. Arora M, Asha S, Chinnappa J, Diwan AD. Review article: burnout in emergency medicine physicians. Emerg Med Australas 2013;25(6):491-5.

14. Medscape lifestyle survey. Available at: http://www.meds cape.com/features/slideshow/lifestyle/2015/public/overview (accessed 8 September 2017).

15. Rossouw L, Seedat PS, Emsley PR, et al. The prevalence of burnout and depression among medical doctors working in the Cape Town metropole community health care clinics and district hospitals of the Provincial Government of the Western Cape: A Cross-Sectional Study; 2011. Available at: http://scholar.sun.ac.za/handle/10019.1/46747 (accessed 8 September 2017).

16. Health Professions Council of South Africa. Available at: http:// isystems.hpcsa.co.za/iregister (accessed 8 September 2017).

17. Royal College of Physicians and Surgeons of Canada. Available at: http://www.royalcollege.ca/portal/page/portal/ rc/about/help/contact (accessed 8 September 2017).

18. Affleck A, Dodd G, Drummond A, et al. The future of emergency medicine in Canada: submission from CAEP to the Romanow Commission. Part 2. CFEM 2002;4(6):431-8.

19. Kerr R, McHugh M, McCrory M. HSE management standards and stress-related work outcomes. Occup Med (Lond) 2009;59(8):574-9. 
20. Brookes K, Limbert C, Deacy C, et al. Systematic review: work-related stress and the HSE management standards. Occup Med (Lond) 2013;63(7):463-72.

21. Cousins R, MacKay CJ, Clarke SD, et al. "Management Standards" work-related stress in the UK: practical development. Work Stress 2004;18(2):113-36.

22. MacKay CJ, Cousins R, Kelly PJ, Lee S, McCaig RH "Management Standards" and work-related stress in the UK: policy background and science. Work Stress 2004;18(2):91-112.

23. Ulmer C, Wolman DM, Johns MM. eds Committee on optimizing graduate medical trainee (resident) bours and work schedule to improve patient safety, Institute of medicine. Washington DC: The National Academic Press; 2008.
24. Ulmer C, Wolman DM, Johns MM. editors Resident duty hours: enhancing sleep, supervision, and safety. Washington DC: National Academic Press; 2009.

25. Asch DA, Bilimoria KY, Desai SV. Resident duty hours and medical education policy - raising the evidence bar. $N$ Engl 7 Med 2017;2017(376):1704-6.

26. Basu S, Yap C, Mason S. Examining the sources of occupational stress in an emergency department. Occup Med (Lond) 2016;66(9):737-42.

27. Howlett M, Doody K, Murray J, et al. Burnout in emergency department healthcare professionals is associated with coping style: a cross-sectional survey. Emerg Med 7 2015; 32(9):722-7. 